\title{
The capitalist diet: Energy-dense and profitable
}

\author{
Review by Nicholas Freudenberg, City University of New York *
}

Review of The Neoliberal Diet: Healthy Profits, Unhealthy People by Gerardo Otero. (2018). Published by University of Texas Press. Available in hardcover and paperback; 256 pages. Publisher's website: https://utpress.utexas.edu/books/otero-the-neoliberal-diet

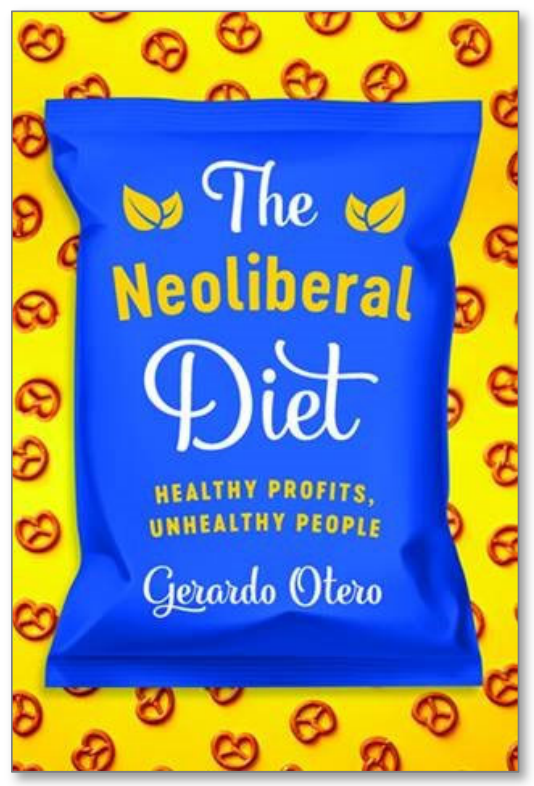

Submitted March 4, 2019 / Published online July 9, 2019

Citation: Freudenberg, N. (2019). The capitalist diet: Energy-dense and profitable [Book review]. Journal of Agriculture, Food Systems, and Community Development, 9(1), 139-140. https://doi.org/10.5304/jafscd.2019.091.013

Copyright (C 2019 by the Author. Published by the Lyson Center for Civic Agriculture and Food Systems. Open access under CC-BY license.

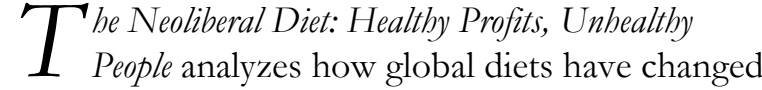
in recent decades, what caused these changes, and who loses and gains by the transformation. Author Gerardo Otero is a professor of international studies at Simon Fraser University in Vancouver, Canada, and the author of several previous books on the global food system. In the book, Otero describes how the global diet that emerged at the turn of the $21^{\text {st }}$ century has contributed to worldwide increases in overweight and obesity and how neoliberalism, the variant of capitalism that evolved in this period, promotes obesogenic diets.

Neoliberalism posits that markets are best equipped to solve all problems and that by deregulating, privatizing, and emphasizing

* Nicholas Freudenberg is Distinguished Professor of Public Health and director of the CUNY Urban Food Policy Institute at City University of New York. His most recent book is Lethal but Legal: Corporations, Consumption, and Protecting Public Health (Oxford, 2016). He can be contacted at Nick.Freudenberg@sph.cuny.edu. individual responsibility, governments can unleash capitalist economies for growth (Harvey, 2007). Harvey describes neoliberalism as the corporate capitalist class's political response to the threats to their control that emerged in the late 1960s and 1970s.

Otero makes several points that warrant the attention of food policy analysts and advocates. First, he shows how changes in global food regimes such as the growth of corporate managed food trade, the consolidation of agribusiness and food sectors into a handful of giant transnational corporations, and the industrial production of corn, soy, and sugar have created a new global diet. Carlos Monteiro, a Brazilian nutritionist, and his colleagues call the energy-dense, nutrient-poor, highly processed foods that these companies produce ultraprocessed food (Monteiro et al., 2019). Their research shows that ultraprocessed food constitutes a growing share of calories consumed in high-income countries and is rapidly gaining in low- and middle-income countries. Ultraprocessed 
food has been associated with the rise of dietrelated diseases and obesity (Monteiro, Moubarac, Cannon, Ng, \& Popkin, 2013).

Second, Otero makes the case that the neoliberal diet exacerbates inequities between what low-income and wealthier people eat. Ultraprocessed food is generally cheaper and more available than healthier food and therefore is consumed more by the poor, while the better off can afford what Otero calls luxury foods-year-round fresh fruits and vegetables, whole grains, and some kinds of meat. Around the world, inequitable access to healthy food is becoming the leading driver of inequitable rates of premature deaths and preventable illnesses from diet-related diseases (Peeters \& Blake, 2016), a dire consequence of the globalization of the neoliberal diet.

Third, Otero coins the term "neoregulation" (pp. 39-43) to describe regulations that arise from partnerships between corporations and governments. He observes that neoliberalism not only deregulates but also shifts the focus of government oversight from protecting consumers to protecting corporations. Neoregulation emphasizes the protection of intellectual property rights for agribusinesses, voluntary public-private partnerships as an alternative to mandatory government regulations, and using public support to enlist universities and scientists in corporate research. According to Otero, neoregulation supports the evolving cooperation between national governments and corporations that characterizes neoliberalism.

The changing role of government leads
Otero to make a fourth point: governments can play an important role in protecting populations against harmful dietary changes. Some countries, even while engaging with the global economy and international trade, have made it a priority to safeguard their farmers and agricultural sectors, as a way to supply their own populations with real food and promote local economic development (p. 158). Until recently, Brazil illustrated this approach (Fukuda-Parr, 2018). Thus, he advocates efforts by civil society to pressure governments to defend farmers and eaters in the face of the embrace of the neoliberal food regime by corporations and high-income countries.

Finally, Otero highlights the roles of social movements in resisting neoliberalism and creating alternatives. He describes the role of social movements in the United States and elsewhere in improving conditions for food workers, taxing unhealthy commodities, protecting small farmers, expanding public food procurement, regulating the genetic modification of food, and enforcing antitrust laws. These mobilizations challenge the dominant neoliberal food system and create spaces for testing more transformative reforms.

By engaging with other social movements, including those for strengthening democracy, defending immigrants, creating a universal health care system, and expanding the rights of workers, women, and other excluded groups, the food justice movement can contribute to the idea that another world - and another diet - are in fact possible.

\section{References}

Fukuda-Parr, S. (2018). Developmental states, neoliberalism, and the right to food: Brazil and South Africa. In G. MacNaughton \& D. F. Frey (Eds.), Economic and social rights in a neoliberal world (pp. 217-235). Cambridge: Cambridge University Press. https://doi.org/10.1017/9781108284691.011

Harvey, D. (2007). A brief history of neoliberalism. Oxford: Oxford University Press.

Monteiro, C. A., Cannon, G., Levy, R. B., Moubarac, J.-C., Louzada, M. L., Rauber, F., . . Jaime, P. C. (2019). Ultra-processed foods: What they are and how to identify them. Public Health Nutrition, 22(5), 936-941. https://doi.org/10.1017/S1368980018003762

Monteiro, C. A., Moubarac, J.-C., Cannon, G., Ng, S. W., \& Popkin, B. (2013). Ultra-processed products are becoming dominant in the global food system. Obesity Reviews, 14(S2), 21-28. https://doi.org/10.1111/obr.12107

Peeters, A., \& Blake, M. R. C. (2016). Socioeconomic inequalities in diet quality: From identifying the problem to implementing solutions. Current Nutrition Reports, 5(3), 150-159. https://doi.org/10.1007/s13668-016-0167-5 